\title{
DESIGN AND FABRICATION OF PORTABLE MATERIAL PACKING MACHINE
}

\section{USMAN GHANI, MUBASHIR HAYAT \& ZIA UR REHMAN}

Department of Mechanical Engineering, University of Engineering and Technology Peshawar, Jalozai Campus, Pakistan

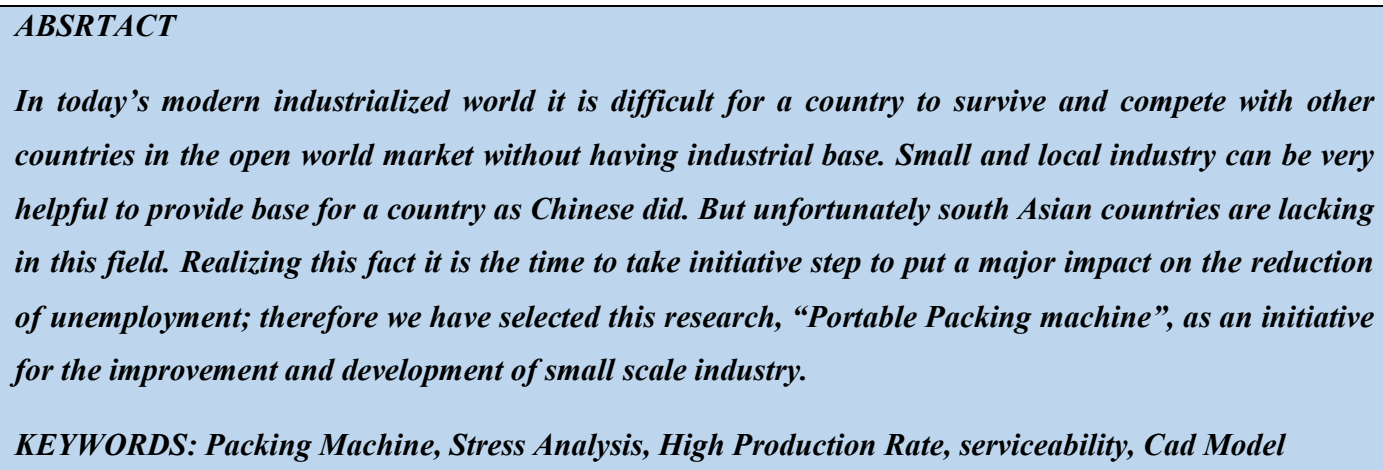

Received: Dec 28, 2020; Accepted: Jan 18, 2021; Published: Feb 03, 2021; Paper Id.: IJMPERDFEB20217

\section{INTRODUCTION}

Packing machine is used to pack different types of materials into small sachets. It is a pure mechanical project. In the early days total work of pouring the material in fixed amounts was done by the operator manually and there was a dedicated apparatus of heating and sealing. There was no concept of automation. The main disadvantage was low production rate, full involvement of operator, wastage of time and worker was unsafe. Manually operated machine was transformed into semi-automated machines by adding some god features to basic mechanism of the manually operated machine. In this machine pouring and sealing were cased into a single machine but still run manually .this type of automation is called mechanical automation. Modern machines are fully automated which reduced operator work into simple supervising. Nowadays new versions are also available.

Packaging Machine design and fabrication services includes packaging machinery for packaging materials from different types of manufacturers. A packaging machinery manufacturer creates machinery for packing needs ranging from cartons and boxes to filling and closing machines to wrapping machines, encompassing every possible phase of manufacture necessary to bring a product to market. Some companies that offer packaging equipment design and fabrication services specialize in plastic packaging such as containers or protective packing materials. A plastic packaging manufacturer creates blister packaging, plastic bottles and bags, shrink-wrapping and sealing machinery. Organizations that offer packaging equipment design and packaging equipment fabrication services may specialize in the selection of materials that go into the packaging process. Packaging equipment components include specialty software packages for machine control, hydraulic and pneumatic components, and electronic sensing systems. Packaging material manufacture includes the making of cellulose and cellophane, coatings, corrugated fiberboard and paperboard, plastic films and resins.

The need to improve a packaging system of a company was the idea that impelled the realization of this mechatronics project. So taking into account the significance that represented for the company the acquiring of a 
mechanism that would allow the upgrading of the product, at a low cost, this research was developed; where, first of all, the type of machinery that would be able to take effect according to the characteristics of the substances to be packed was examined; then, the design parameters were analyzed in order to verify, that the machine complied with the specifications and rules established, and finally the construction of a prototype that described the different stages of the packaging process emphasizing the technical and economic solutions that were presented for the company, was developed. The machine uses two types of actuating system: electrical and pneumatic. The electric system controls the security of the machine, the temperature control of the sealing, and also actuates the pneumatic system which actuates the dosing valve and the horizontal seal. The interaction between these systems and also with a third component related with legal rules from a food engineering point of view allowed us to conceive the machine as a mechanical design.

The source of power to system is an electric motor which runs at very high speed. But our required speed for rotating tub is much lower as compared to motor, so to compensate for this large difference between input and output speed, we used double pulley to reduce speed. And then gear mechanism is used to provide power to different components of the machine. As a result of this arrangement the tub, rollers and the cutters gets required speed .There are different houses in the tub which are filled with material timely and in accurate amount. As the tub rotates a pin and cam arrangement closes and opens the houses at correct position and pours the packing material into the wrappers. The wrappers are then sealed continuously by the hot roller and then passed over foam rollers to press the seals. As a result a batch of sachets is obtained which are cut by rotating cutters in required position and so is the required product.

\section{LITERATURE REVIEW}

In the present-day society, the commercialization of a product is not conceived, whichever its nature, without the use of any type of container or packing that contains it and protects it since its primary production until it reaches the consumer; this establishes the importance of alimentary technology [1]. Along the years, thanks to the incursion of machinery in the packaging industry [2]; all types of containers, forms, and designs have been developed, using different materials, to answer the specific needs of the industry and the consumers [3]. The technological development at a local level has been limited to big companies due to the investment that this implicates, denying the possibility to many businessmen to see packaging as a technical and economic function that would be able to minimize costs and maximize sales [4]. In many places it is very common to find products packed manually by its employees without any type of sanitary control on who does this job, neglecting completely the quality of the product. This frequent situation makes the consumer the main victim. In addition, few companies know the advantages that they can to apply technology to tech the packing process of their products (quality and economy), since at glance the raised costs offered in the market are not reachable to many of the possible clients that do not have enough resources in their companies for such an investment [5]. For the realization of this project, one kept in mind the proposal of diverse companies of the sector of fast foods, which besides producing a special type of food also produce the sauces that accompany it. The packing managed by these companies for their sauces, is a completely manual system, which requires an employee in charge of filling each cup as they dispatch orders. This is how this project evolved, looking for a design of a functional and economic machine, that may be manipulated by nonspecialized labor force, bringing up together conditions of simplicity, quickly and quality, with the aim of making the companies begin to consider the different advantages, possibilities and facilities that can be acquired when they invest in new machinery and thus increasing the number of business that can be part of projects in search of technological development necessary for any company even more when they are focused into upgrading the quality of the products 
offered.

Xueping Li et al [6] study the problem of minimizing the makespan for jobs on a single batch processing machine (BPM). A BMP can process several jobs as a batch simultaneously. Unlike the classic batch processing machine scheduling problems in which the capacity of a machine is modeled as one-dimensional knapsack constraints, in this research, the machine's capacity is represented by a two-dimensional rectangle and a job occupies a rectangle of its dimensions, i.e., width and height, while being processed on the machine. Li, H et al [7] proposed a Virtual machine (VM) packing plays an important role in improving resource utilization in cloud data centers. Recently, memory content similarity among VM instances has been used to speed up multiple VM migration in large clouds. Based on this, many VM packing algorithms have been proposed, which only considered the memory capacity of physical machines (PMs) as the resource constraint. Masson, R [8] designed a machine whose propose is an efficient Multi-Start Iterated Local Search for Packing Problems (MS-ILS-PPs) met heuristic for Multi-Capacity Bin Packing Problems (MCBPP) and Machine Reassignment Problems (MRP). The MCBPP is a generalization of the classical bin-packing problem in which the machine (bin) capacity and task (item) sizes are given by multiple (resource) dimensions.

MA Mostert et al [9] proposed a report which outlines standard tests for validating the clean ability of packaging machines. All aspects of the process are considered, from simple commissioning tests, through to the detailed procedures required before using a packaging machine with product. The EHEDG is an independent consortium formed to develop guidelines and test methods for the safe and hygienic processing of food. Yosep Oh et al (2018) produced a large object within a limited workspace of an Additive Manufacturing (AM) machine, this study proposes a two-phase method: (1) part decomposition to separate a part into several pieces; and (2) 2D batch placement to place the decomposed parts onto multiple batches. In Phase 1, the large object is re-designed into small pieces by a Binary Space Partitioning (BSP) with a hyperplane, where parts are decomposed recursively until no parts are oversize the limited size of the workspace. In Phase 2 , the decomposed parts are grouped as batches to go through serial build processes using a single AM machine. Machu et al [10] Provided a details of a new high-performance packing ring design that is characterized by both its high sealing efficiency and low wear rate. As this article shows, clarifying the thermo-physical processes in a pressure packing, gaining an understanding of the wear pattern of a packing ring and elucidating the factors governing the sealing efficiency of a packing ring have played key roles in the development of this design.

\section{DESIGN OF MECHANICAL COMPONENTS}

Following items were selected and their design and selection values are as below 
Table 1: Design of Rotating Tub and Roller

\section{Design of Rotating Tub:}

The objective is to pack 78 packets per minute.

Holes in the tub $=6$

So the required $\mathrm{rpm}$ is $=78 / 6$

Diameter of the tub is 18 in

\section{Design of Rollers}

Design is based on the following factor:

Length of packet without seal $=2.14$ in

Length of the center seal on one side $=0.5$

Length of the packet with seal $=3.14$ in

Width of the packet without seal $=2$

Width of the seal on one side only $=0.5$

Width of the packet with seal $=3$

Numbers of packets in one revolution of heater $=4$

So total circumference $=4 *$ length of packet with seal $=4 * 3.14=12.56$

But circumference $=\pi *$ diameter

So diameter of the heater is $=4$

Table 2: Selection of Motor and its Power

\begin{tabular}{|c|c|}
\hline Inertial Power to Rotating Tub: & Inertial Power to hot roller \\
\hline $\begin{array}{l}\text { Suppose the angular speed becomes uniform after one } \\
\text { revolution } \\
\text { Power to tub }(\mathrm{p})=2 * \pi * \mathrm{n} * \mathrm{~T} /(60 * 746) \mathrm{hp} \\
\mathrm{D} 1=18 \mathrm{in} \\
\mathrm{D} 2=1 \mathrm{in} \\
\mathrm{K}=0.2159 \mathrm{~m} \\
\text { Mass of the rotating tub is }=4 \mathrm{Kg} \\
\mathrm{I}=4 *(.2159) 2 / 2 \\
\mathrm{I}=0.1 \mathrm{Kg} \mathrm{K}^{*} \mathrm{~m} 2 \\
\omega \mathrm{f}=2 * \pi * \mathrm{n} / 60=1.36 \mathrm{rad} / \mathrm{s} \\
\omega \mathrm{i}=0 \\
\alpha=(\omega \mathrm{f} 2-\omega \mathrm{i} 2) /(2 * 2 \pi)=147 \mathrm{rad} / \mathrm{s} 2 \\
\mathrm{~T}=0.0147 \mathrm{Nm} \\
\text { Power }=0.02685 \mathrm{hp}\end{array}$ & $\begin{array}{l}\text { Torque }(\mathrm{T})=2 * \pi * \mathrm{nr} * \mathrm{~T} /(60 * 746) \mathrm{hp} \\
\mathrm{k}=(\mathrm{D} \mathrm{r} 1-\mathrm{D} \mathrm{r} 2) / 2 \\
\mathrm{D} \mathrm{r} 1=4 \mathrm{in} \\
\mathrm{Dr} 2=2 \mathrm{in} \\
\mathrm{k}=0.0254 \mathrm{~m} \\
\text { Mass of the rotating heater is }=3.65 \mathrm{Kg} \\
\mathrm{Ir}=3.65 *(0.0254) 2 / 2 \\
\mathrm{Ir}=.00117 \mathrm{Kg} * \mathrm{~m} 2 \\
\omega \mathrm{f}=2 * \pi * \mathrm{nr} / 60 \\
\omega \mathrm{i}=0 \\
\omega \mathrm{f}=2.04 \mathrm{rad} / \mathrm{s} \\
\alpha=(\omega \mathrm{f} 2-\omega \mathrm{i} 2) /(4 * \pi) \\
\alpha=0.3316 \mathrm{rad} / \mathrm{s} 2 \\
\mathrm{So}, \mathrm{Tr}=3.88 \mathrm{e}-4 \mathrm{Nm} \\
\mathrm{For} \text { two rollers total Power }=2.123 \mathrm{e}-3\end{array}$ \\
\hline Inert & \\
\hline
\end{tabular}




\begin{tabular}{l|l|}
\hline $2 * \pi * n_{\mathrm{s}} * \mathrm{~T} /(60 * 746) \mathrm{hp}$ & \\
Torque $(\mathrm{T})=\mathrm{Is} * \alpha$ & \\
$\mathrm{I}_{\mathrm{s}}=\left(\mathrm{m}^{*} \mathrm{~K}^{2}\right) / 2$ & \\
$\mathrm{D}_{\mathrm{s} 1}=3 \mathrm{in}$ & \\
$\mathrm{D}_{\mathrm{s} 2}=2 \mathrm{in}$ & \\
$\mathrm{k}=0.0245 \mathrm{~m}$ & \\
Mass of the rotating foam roller is $=1 \mathrm{Kg}$ & \\
$\mathrm{I}_{\mathrm{s}}=3.225 \mathrm{e}-4$ & \\
$\omega_{\mathrm{f}}=2 * \pi * \mathrm{~N} / 60$ & \\
$\omega_{\mathrm{i}}=0$ \\
$\omega_{\mathrm{f}}=2.041 \mathrm{rad} / \mathrm{sec}$ \\
$\alpha=\left(\omega_{\mathrm{f}}^{2}-\omega_{\mathrm{i}}^{2}\right) /(4 * \pi)$ \\
$\alpha=.3316 \mathrm{rad} / \mathrm{s}^{2}$ & \\
So, Ts $=1.07 \mathrm{e}-4$ & \\
Power $=2.292 \mathrm{e}-4 \mathrm{hp}$ & \\
Calculation & \\
Total inertial power: sum of all inertial power $=0.02926$ & \\
hp & \\
&
\end{tabular}

\subsection{Design of Shaft}

Shaft is rotating member, usually of circular cross section used to transmit power or motion. It provides axes of rotation to elements such as gears pulleys and fly wheels and controls the geometry of their motion. The design of the machine itself will dictate that certain gears pulleys bearings and other element will have at least been practically analyzed and their size and spacing tentatively determined. The geometry of the shaft is that of a stepped cylinder. Although a uniform diameter cold drawn round would require no finishing cuts and appear to be inexpensive, it would difficult to locate bearings, gears, and other members on it in a positive manner. Torsional Stresses have a major impact on failure of the shafts. These shaft stresses are due to the torque which shaft must carry.

$\tau_{\max }=\mathrm{T}^{*} \rho / \mathrm{J}=16^{*} \mathrm{~T} / \pi * \mathrm{~d}^{3}$

Bending stresses are present due to bending moment present in beams due to deflection

$\sigma_{b}=\mathrm{M} * \mathrm{y} / \mathrm{I}=32 \mathrm{M} / \pi * \mathrm{~d}^{3}$

The shaft is transmitting 0.3 horsepower

$\mathrm{P}=0.3 \mathrm{hp}=223.8 \mathrm{~W}$

Angular velocity of the shaft

$\omega=2 * \pi * n / 60$

$\omega=2 * \pi * 78 / 60$

$\omega=8.168 \mathrm{rad} / \mathrm{sec}$ 


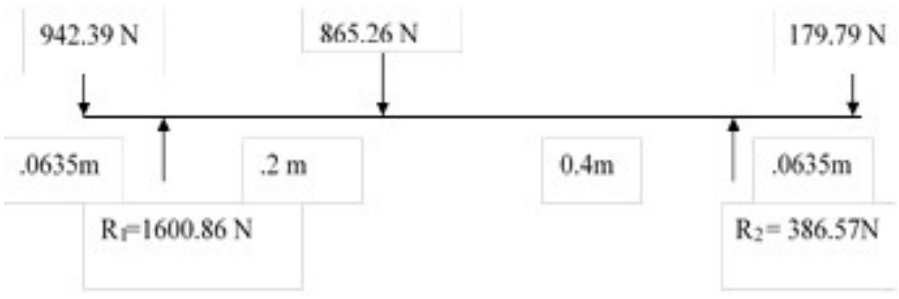

\section{Loading Diagram of the shaft}

Torque $=$ Power $/$ Angular Velocity

$\mathrm{T}=0.3 * 746 / 8.168$

$\mathrm{T}=27.399 \mathrm{~N} . \mathrm{m}$

Torque consumed in pinion $=\mathrm{T} 1=10.96 \mathrm{Nm}$

Torque consumed in worm $=\mathrm{T} 2=16.44 \mathrm{Nm}$

Force on pinion $=\mathrm{T} 1 / \mathrm{r} 1=942.39 \mathrm{~N}$

Force on worm $=\mathrm{T} 2 / \mathrm{r} 2=865.26 \mathrm{~N}$

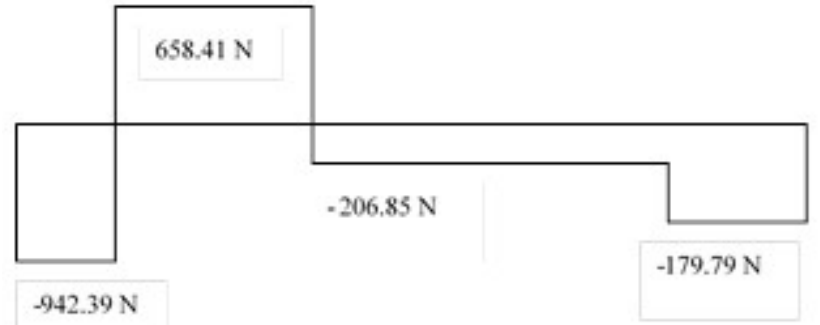

Shear Force Diagram of the Shaft

From the loading diagram

$\sum F y=0$

$\mathrm{R} 1+\mathrm{R} 2=1987.433$

$\sum \mathrm{M} 1=0$ gives

$\mathrm{R} 1=1600.8 \mathrm{~N}$

$\mathrm{R} 2=386.57 \mathrm{~N}$

From the diagram

$\mathrm{M}_{\max }=71.68 \mathrm{~N} . \mathrm{m}$

Using max shear stress theory

$\mathrm{d}=\left[(32 * \mathrm{n}) /\left(\pi^{*} \mathrm{Sy}\right)\{\mathrm{M} 2+\mathrm{T} 2\} 1 / 2\right] 1 / 3$

Factor of safety $n=1.5$ 


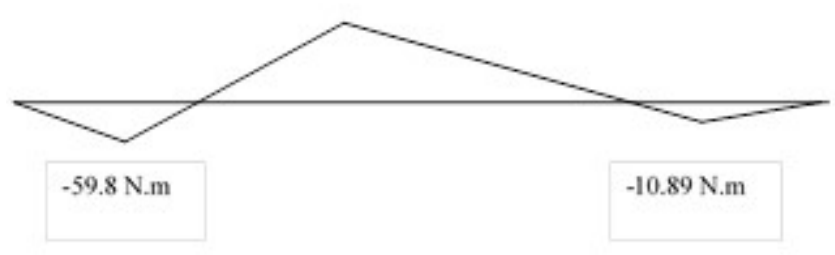

Bending Moment Diagram of the Shaft

Sy $=470 \mathrm{Mpa}$

$d=\left[(32 * n) /\left(\pi^{*} \text { Sy }\right)\left\{M^{2}+T^{2}\right\}^{1 / 2}\right]^{1 / 3}$

$\mathrm{d}=0.01346 \mathrm{~m}=0.53$ in

\subsection{Design of Gear}

Gears, as defined by the AGMA (American Gear Manufacturing Association) are machine elements that transmit motion by means of successively engaging teeth. There are many types of gears used for power transmission from one shaft to another. Gears used in our project are spur gears, worm and worm gear. If the face width is less than three times the circular pitch, a larger gear is needed to carry load per inch of the face width. Large gear requires more space in gear enclosure and makes the machine bigger and more expensive. Large gears are more expensive to manufacture and also machine has usually slower production rate. The total procedure is to select a trial value for the diameter pitch and then to make the following successive calculations:

- The pitch diameter $\mathrm{d}$ in inches from the equation, $\mathrm{d}=\mathrm{N} / \mathrm{P}$

- The line velocity $\mathrm{V}$ in inch per minute, $\mathrm{V}=3.14{ }^{*} \mathrm{~d}^{*} \mathrm{n}$

- The transmitted load $\mathrm{Wt}$ in pounds, $\mathrm{Wt}=33000 * \mathrm{H} / \mathrm{V}$

- The velocity factor, $\mathrm{Kv}=1200+\mathrm{V} / 1200$

- The face width $\mathrm{F}$ in inches, $\mathrm{F}=\mathrm{Wt} * \mathrm{P} / \mathrm{Kv}^{*} \mathrm{Y} * \sigma \mathrm{p}$

- $\quad$ The minimum and maximum face width $3 p$ and $5 p$

Spur gears are usually used for rotary motion between parallel shafts; they are usually in cylindrical form. Starting our all design procedure is in accordance to our required out put. Our required out put speed of the rotating tub is $13 \mathrm{rpm}$. We used spur gears to obtain the required speed ratio. 
Table 3: Gears Selection

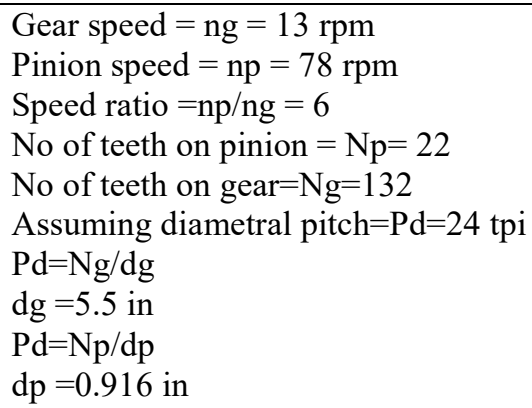

Table 4: Force and Stress Analysis of Components

\begin{tabular}{|c|c|}
\hline Force Analysis & Stress Analysis \\
\hline $\begin{array}{l}\text { 1. Power loss in belts }=1 \% \\
\text { 2. Power loss in chains }=5 \% \\
\text { 3. Power loss in gears }=4 \% \\
\text { 4. Power loss due to opening mechanism }=6 \% \\
\text { 5. Inertial power }=0.02926 \mathrm{hp} \\
\text { 6. As a result of all losses the power available at spur gear } \\
\mathrm{set}=.05 \mathrm{hp} \\
\mathrm{P}=\mathrm{wt} * \mathrm{v} / 33000 \\
\mathrm{~V}=\pi^{*} \mathrm{~d}^{*} \mathrm{n} / 12=18.71 \mathrm{ft} / \mathrm{min} \\
\mathrm{Wt}=\mathrm{P} * 33000 / \mathrm{V}=88.18891 \mathrm{~b} \\
\mathrm{Wr}=\mathrm{Wt} * \tan 200=32.091 \mathrm{~b} \\
\mathrm{~W}=\sqrt{ }(\mathrm{Wr} 2+\mathrm{Wt} 2)=93.84 \mathrm{lb}\end{array}$ & $\begin{array}{l}\text { Base on Lewis formula } \\
\text { For bending stresses } \\
\text { Formula: } \\
\delta \text { all }=\mathrm{Wt} * \mathrm{P} / \mathrm{Kv}^{*} \mathrm{~F}^{*} \mathrm{Y} \\
\text { For pinoin } \mathrm{Y}=0.331 \\
\text { Face width } \mathrm{F}=.4 \\
\mathrm{Kv}=1200+\mathrm{V} / 1200=1.0115 \\
\delta \text { all }=15.804 \mathrm{Kpsi} \\
\delta \mathrm{y}=31 \mathrm{Kpsi} \\
\text { Factor of safety }=\mathrm{F} . \mathrm{O} . \mathrm{S} .=\delta \mathrm{y} \quad / \delta \text { all }=1.961\end{array}$ \\
\hline
\end{tabular}

\subsection{Chains, for Worm Wheel and Hot Roller Design}

Chains are also used for transmission of power over long distances. The basic feature of chain drives includes a constant ratio, since no slippage or creep is involved, long life, and the ability to drive a number of shafts from a single source of power. We have selected 10 teeth sprocket and ANSI Chain No.40 because it fulfilled our requirement easily and also because of its low cost and easily availability in market. It gives power to hot roller from worm wheel shaft. We have selected 14 teeth sprockets and ANSI Chain No.40. 
Table 5: Chains Related Design

\begin{tabular}{|c|c|}
\hline Chains Calculation & $\begin{array}{l}\text { Chain calculation between Worm Wheel Shaft and Hot } \\
\text { Roller }\end{array}$ \\
\hline $\begin{array}{l}\text { Central distance }=\mathrm{C}=7 \text { inch } \\
\text { Number of teeth on driver sprocket }=\mathrm{N} 1=10 \\
\text { Number of teeth on driven sprocket }=\mathrm{N} 2=10 \\
\text { For ANSI chain No. } 40 \\
\text { Pitch }=\mathrm{P}=0.5 \text { inch } \\
\text { Width }=0.321 \text { inch } \\
\text { Pitch Length of chain } \\
\mathrm{L} / \mathrm{P}=2 \mathrm{C} / \mathrm{P}+(\mathrm{N} 1+\mathrm{N} 2) / 2+(\mathrm{N} 1-\mathrm{N} 2) 2 /(4 \pi 2 \mathrm{C} / \mathrm{P}) \\
\mathrm{L}=38 \text { pitches } \\
\text { Rated horse power (for } 78 \mathrm{rpm}) \\
\mathrm{Hr}=0.5492 \text { hp } \\
\text { Corrected horse power } \\
\mathrm{Hr}=\mathrm{K} 1 \mathrm{~K} 2 \mathrm{Hr} \\
\mathrm{K} 1=0.5 \\
\mathrm{~K} 2=1 \\
\mathrm{Hr}=0.2746 \mathrm{hp}\end{array}$ & $\begin{array}{l}\text { Central distance }=\mathrm{C}=10.5 \text { inch } \\
\text { Number of teeth on driver sprocket }=\mathrm{N} 1=14 \\
\text { Number of teeth on driven sprocket }=\mathrm{N} 2=14 \\
\text { Now for ANSI chain No. } 40 \\
\text { Pitch }=\mathrm{P}=0.5 \text { inch } \\
\text { Width }=0.321 \text { inch } \\
\text { Pitch Length of chain } \\
\mathrm{L} / \mathrm{P}=2 \mathrm{C} / \mathrm{P}+(\mathrm{N} 1+\mathrm{N} 2) / 2+(\mathrm{N} 1-\mathrm{N} 2) 2 /(4 \pi 2 \mathrm{C} / \mathrm{P}) \\
\mathrm{L}=56 \text { pitches } \\
\text { Rated horse power (for } 19.5 \mathrm{rpm}) \\
\mathrm{Hr}=0.1748 \mathrm{hp} \\
\text { Corrected horse power } \\
\mathrm{Hr}=\mathrm{K} 1 \mathrm{~K} 2 \mathrm{Hr} \\
\mathrm{K} 1=0.78 \\
\mathrm{~K} 2=1 \\
\mathrm{Hr}=0.146 \mathrm{hp}\end{array}$ \\
\hline Chain between Hot Roller and Foam Roller & \\
\hline $\begin{array}{l}\text { It gives power to foam roller from hot roller } \\
\text { Central distance }=\mathrm{C}=8.5 \text { inch } \\
\text { Number of teeth on driver sprocket }=\mathrm{N} 1=11 \\
\text { Number of teeth on driven sprocket }=\mathrm{N} 2=11 \\
\text { Now for ANSI Chain No. } 40 \\
\text { Pitch }=\mathrm{P}=0.5 \text { inch } \\
\text { Width }=0.321 \text { inch } \\
\mathrm{Pitch} \text { Length of chain } \\
\mathrm{L} / \mathrm{P}=2 \mathrm{C} / \mathrm{P}+(\mathrm{N} 1+\mathrm{N} 2) / 2+(\mathrm{N} 1-\mathrm{N} 2) 2 /(4 \pi 2 \mathrm{C} / \mathrm{P}) \\
\mathrm{L}=45 \mathrm{pitches} \\
\mathrm{Rated} \text { horse power } \text { (for } 19.5 \mathrm{rpm}) \\
\mathrm{Hr}=0.1748 \mathrm{hp} \\
\mathrm{Corrected} \text { horse power } \\
\mathrm{Hr}=\mathrm{K} 1 \mathrm{~K} 2 \mathrm{Hr} \\
\mathrm{K} 1=0.53 \\
\mathrm{~K} 2=1 \\
\mathrm{Hr}=0.1 \mathrm{hp} \\
\mathrm{It} \text { shows that chain being selected fulfills our requirement. }\end{array}$ & \\
\hline
\end{tabular}

\section{MATERIAL}

Carbon is one of the most important elements of steel. It influences the strength of metal greater than that of any other element. Mild steel has $0.45 \%$ to $0.8 \%$ of carbon. The mechanical properties can be controlled by the composition of the alloying element and by heat treatment. The selection problem is usually one of choosing from large number of available steels grades. Mild steel is extensively used in the application where members are subjected to high stresses due to external loads, stress concentration and in parts subjected to wear, high or low temperature or corrosion. It is commonly used in machine parts as crankshaft, connecting rods, gears, shafts, keys, Pins, rivets, bolts, and frames of machines etc.

\subsection{Material of Bearing}

Bearing components are subjected to cyclic loading so they are mostly failed because of the fatigue failure. Hence proper 
material should be selected to withstand with the working stresses induced during their operation. The outer and inner rings are made of mild steel and the balls are made of cast iron. Cast iron is used because of its easy machine ability and resistance to wear. Mostly hardened alloy of steel is used.

\subsection{Material of Gear}

Gears are commonly made of steel, cast iron. There is a great variety of material available for the designer, so that he can have the opportunity of obtaining the optimum material for any particular requirement. Normally the selection is based on the high strength, long life and quietness of operation or high reliability. Steel is the only satisfactory material because it combines both high strength and low cost. The choice of gear material selection depends on the type of working stresses. Cast iron is a very useful gear material because it has good wear resistance. It is easy to cast, machined and transmit less noise. The gears used in our project are made of mild steel.

\section{PRO-ENGINEERING AND ANSYS SECTION}

Pro/Engineer is the high quality fast 3D modeling software commonly used in design industries throughout the world. Its powerful graphics facilitate a user to enhance his model easily. Pro/E wildfire version 2.0 has been used to generate 3D models of all the parts of the project, sub assemblies by combining the parts and the machine by combining all the subassemblies. Various steps and components are given below:

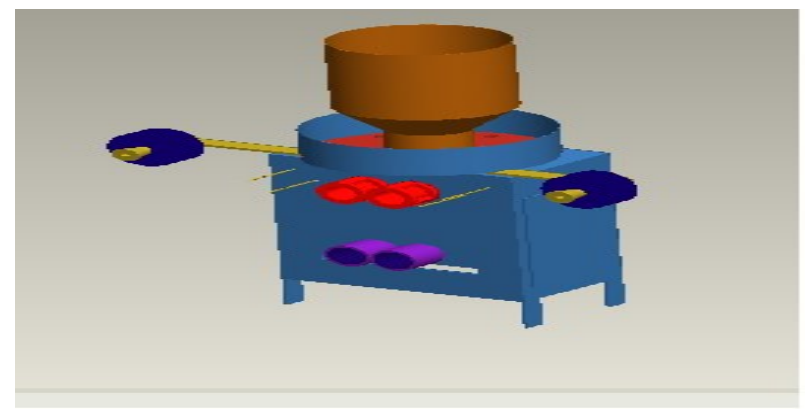

Figure 1: PRO-E Model

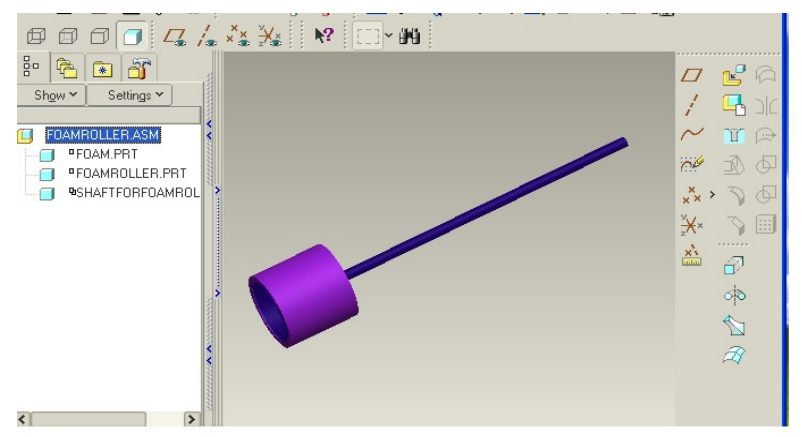

Figure 3: Foam roller

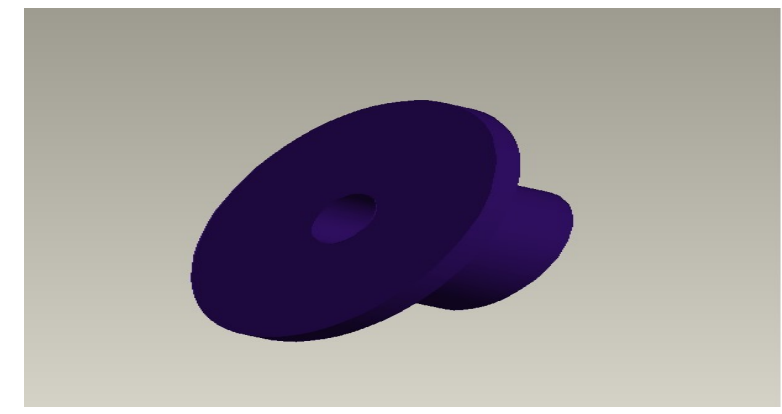

Figure 2: Seat for Tub

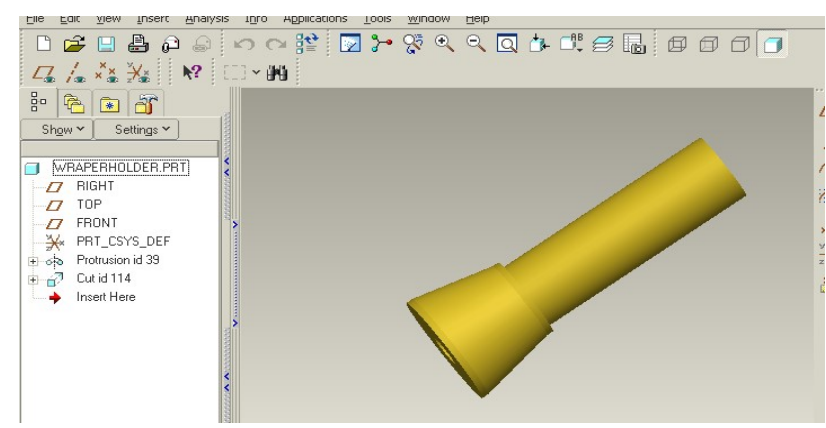

Figure 4: Holders 


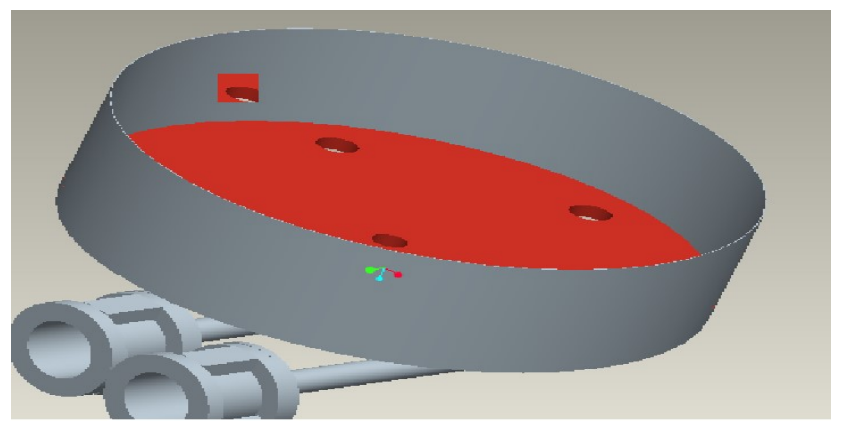

Figure 5: Rotating Tub

\subsection{Cost Analysis of Project:}

Table 6: Cost of various components

\begin{tabular}{|l|l|l|l|l|l|}
\hline \multicolumn{1}{|c|}{ Item } & \multicolumn{1}{|c|}{ Quantity } & \multicolumn{1}{|c|}{ Size } & \multicolumn{1}{c|}{ Most } & \multicolumn{1}{c|}{ Mass } & \multicolumn{1}{c|}{ Price(Rupees) } \\
\hline Cost of $1 / 8$ in sheet & 2 & $1 / 8 * 8 * 15$ & 50 per kg & I kg & 100 \\
\hline Cost of $2 / 8$ in sheet & & $20 * 24$ in & 50 Per Kg & $40 \mathrm{~kg}$ & 2000 \\
\hline Cost of storage and tub & 1 & & & & 700 \\
\hline Cost of power shaft & 1 & $0.5 * 26$ in & & & 300 \\
\hline Cost of shaft & 3 & $15 * 1$ in & & & 700 \\
\hline Cost of rollers (MS) & 4 & & & & 1500 \\
\hline Cost of pinion and spur & 4 & & & & 1280 \\
\hline Cost of sprockets & 6 & & & & 320 \\
\hline Cost of worm and & 1 & & 1000 & & 1000 \\
\hline Cost of chain & 3 & & 40 per item & & 120 \\
\hline Cost of sheaves & 4 & & & & 410 \\
\hline Cost of bearing & 9 & & 40 per item & & 380 \\
\hline Cost of bolts ant nuts & 40,30 & $5 / 16$ in*1 in & 2 per item & & 140 \\
\hline Cost of belts & 2 & & & & 80 \\
\hline Cost of labor & & & & & 3000 \\
\hline Cost of paint & 1 & & & & 120 \\
\hline Miscellaneous cost & & & & & 2000 \\
\hline Grand cost & & & & 14150 \\
\hline
\end{tabular}

\section{CONCLUSIONS}

This project was selected with the aim of providing a smart step towards home industry. After the conclusion drawn from a broad survey report the project was selected and the objectives were specified. By the grace of Allah and our devotion made it possible to complete it with in time, achieving our desired objectives. The following features of the project "Design and Fabrication of Packing Machine" make it attractive for the manufacturer and for the public who are interested in developing a small home industry.

- $\quad$ Low capital cost.

- $\quad$ Low running cost.

- Low maintenance cost. 
- High production rate.

- Unskilled operator can operate it.

- $\quad$ Compact size.

\section{REFERENCES}

1. EHEDG Update, 2001, "Challenge tests for the evaluation of hygienic characteristics of packing machines for liquid and semi-liquid products” Trends in Food Science \& Technology, Vol. 12, Issue 7, pp. 244-248.

2. Whelan, P.F., Batchelor, B.G. 1996, “Automated packing systems-a systems engineering approach”, IEEE Transactions on Systems, Man and Cybernetics, Part A, Vol. 26, Issue 5, pp. 533 - 544.

3. Dallyn, H. and Shorten, D., 1998, "Hygiene aspects of packaging in the food industry", International Biodeterioration, Vol. 24, Issues 4-5, pp. 387-392.

4. Amerongen, J. V. 2003, “Mechatronic design” Mechatronics, Pergamon, Elsevier. Vol. 13, Issue 10, pp. 1045-1066

5. EHEDG Update, 2001, "Challenge tests for the evaluation of hygienic characteristics of packing machines for liquid and semi-liquid products" Trends in Food Science \& Technology, Vol. 12, Issue 7, pp. 244-248.

6. Li, X., \& Zhang, K. (2018). Single batch processing machine scheduling with two-dimensional bin packing constraints. International Journal of Production Economics, 196, 113-121.

7. Li, H., Li, W., Zhang, S., Wang, H., Pan, Y., \& Wang, J. (2019). Page-sharing-based virtual machine packing with multiresource constraints to reduce network traffic in migration for clouds. Future Generation Computer Systems, 96, 462-471.

8. Masson, R., Vidal, T., Michallet, J., Penna, P. H. V., Petrucci, V., Subramanian, A., \& Dubedout, H. (2013). An iterated local search heuristic for multi-capacity bin packing and machine reassignment problems. Expert Systems with Applications, 40(13), 5266-5275.

9. Mostert, M. A., Arthaud, E., Boisson, J. M., Bovee, E. H. G., Damagnez, E., Golz, P. \& Rysstad, G. (2001). Challenge tests for the evaluation of hygienic characteristics of packing machines for liquid and semi-liquid products. Trends in Food Science \& Technology, 12(7), 244-248.

10. Oh, Y., Zhou, C., \& Behdad, S. (2018). Part decomposition and 2D batch placement in single-machine additive manufacturing systems. Journal of Manufacturing Systems, 48, 131-139.

11. Machu, G. (2011). A new packing ring design-improved sealing efficiency and high durability. Sealing Technology, 2011(9), $8-12$.

12. Shiegley E Joseph (6th Edition) "Mechanical Engineering Design” McGraw Hill

13. Shiegley E Joseph "Hand Book of Machine Design"

14. Singer L.Ferdinand (4 ${ }^{\text {th }}$ Edition) "Strength of Material" Harper International Edition

15. Avner H Sidney (2 ${ }^{\text {nd }}$ Edition) "Introduction to Physical metallurgy" McGraw Hill

16. Chaudry S.K. Hajra (volume II) "Elements of Workshop Technology” Media Promoters and Publishers Pvt Ltd. 